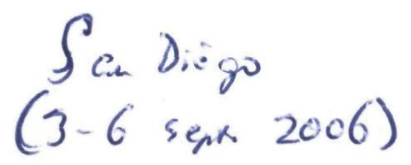

\title{
GOLFKLAP A MODEL TO DETERMINE THE IMPACT OF WAVES ON DIKE STRUCTURES WITH AN ASPHALTIC CONCRETE LAYER
}

\author{
Arjan K. de Looff, KOAC·NPC, delooff@koac-npc.nl \\ Robert 't Hart, Road and Hydraulic Engineering Institute of Rijkswaterstaat, R.t-Hart@DWW.RWS.MinVenW.nl \\ Kees Montauban, Road and Hydraulic Engineering Institute of Rijkswaterstaat (retired) CCMontauban@kabelfoon.nI \\ Martin F.C. van de Ven, Delft University of Technology, m.vandeven@citg.tudelft.nl
}

\section{INTRODUCTION}

The economic heart in the West of the Netherlands lies below sea level and is protected by water defences.

The Dutch law on water defences requires that these vital dikes are evaluated every 5 years with regards the resistance against a super storm. If the dike does not satisfy the requirements immediate action is required. Over 400 kilometers of the Dutch sea dikes have an asphalt revetment (layer thickness mostly $200-300 \mathrm{~mm}$ ) in the wave attack zone, because of the expected excellent performance of this structure in time.

To obtain a scientific based design and evaluation method for asphalt dike revetments, the model GOLFKLAP (wave impact) has been developed.

\section{SCHEMATIZATION OF THE SYSTEM}

The cross section of a dike can be entered into the program with the use of $x$ and $y$-coordinates.

The construction is schematized as an elastic supported beam with small springs (Winkler foundation). The wave impact is schematized as a triangular load on the asphaltic concrete layer (see figure 1).



Figure 1 - schematization of the system

In GOLFKLAP, the bending stress in the construction due to wave loads is determined and compared with the failure stress. To determine the bending stress, the construction is characterized by the layer thickness and the stiffness modulus of the revetment and the bedding value of the subgrade.

\section{FATIGUE}

Asphalt is sensitive to fatigue, i.e. the failure stress of asphalt depends on the number of load repetitions. The value of the failure stress reduces with the increase of the number of loads. The fatigue strength of an asphalt revetment is normally derived with laboratory tests on specimens from the revetment.

\section{WAVE LOADS}

Both place and magnitude of the wave loads on a revetment are variable during a storm. In GOLFKLAP the change of water level during a storm can be entered. The program also takes variations in size and place of the wave impact into account. The result is a distribution of wave loads over the revetment.

\section{MINERS RULE}

Every load adds damage to the construction. To determine whether the revetment is capable of resisting the occurring sum of wave loads, Miners rule is used:

$$
\sum \frac{n_{i}}{N_{f, i}} \leq 1
$$

With:

$\mathrm{n}_{\mathrm{i}} \quad$ number of loads;

$\mathrm{N}_{\mathrm{f}, \mathrm{i}}$ number of loads to failure.

GOLFKLAP calculates this Miner sum. The revetment will collapse if the Miner sum exceeds 1 .

\section{DATA SURVEYING}

To execute a safety assessment of an asphaltic dike revetment, a good insight into the most important parameters of the construction is necessary. Most of the asphalt dikes are older than 20 years. The variation of properties increases in time. Therefore the layer thickness is determined with ground penetrating radar (GPR) and the stiffness modulus with a falling weight deflection meter (FWD). Both methods combined give a good insight in the quality of the revetment. With these results weak spots in the revetment can be allocated. From these weak spots cores are taken for laboratory tests to determine the relation between failure stress and number of load repetitions.

\section{CONCLUSION}

In combination with non-destructive measurements like radar and falling weight deflection GOLFKLAP is a powerful tool for both designing and performing safety assessments on asphaltic dike revetments. 


\title{
GOLFKLAP A MODEL TO DETERMINE THE IMPACT OF WAVES ON DIKE STRUCTURES WITH AN ASPHALTIC CONCRETE LAYER
}

\author{
Arjan K. de Looff' Robert 't Hart' Kees Montauban ${ }^{3}$ Martin F.C. van \\ de Ven ${ }^{4}$
}

GOLFKLAP (wave impact) is a computer program developed to design and evaluate a asphalt dike revetment on wave impacts. The program calculates the occurring bending stresses in the revetment due to wave loads and verifies whether the construction will yield due to fatigue of the material. To calculate the bending stresses the construction is schematized as an elastic beam supported by small springs. The properties from the asphalt revetment can be derived with field measurements and laboratory tests on specimen taken from cores from the revetment.

\section{INTRODUCTION}

Large parts of the Netherlands lie below sea level and are protected by water defences. The Dutch law on water defenses requires that these vital dikes are evaluated every 5 years with regards to the resistance against a super storm. If the dike does not satisfy the requirements immediate action is required. More than 400 kilometers of the Dutch sea dikes have an asphalt revetment (layer thickness mostly $200-300 \mathrm{~mm}$ ) in the wave attack zone, because of the expected excellent performance of this structure in time.

For designing an asphalt dike revetment the following loads have to be considered:

- Water pressure under a watertight revetment after a storm due to a high groundwater level in the dike body

- Wave impacts on the revetment

- Settlement of the sub grade and the dike body

- Ice on the revetment

- Traffic, for example to perform maintenance

The computer model GOLFKLAP (wave impact) has been developed to design and evaluate an asphalt revetment on wave impacts (De Looff et al 2004).

${ }^{1}$ KOAC-NPC, PO-BOX 2756, 3381 BJ, Utrecht, The Netherlands

${ }^{2}$ Rijkswaterstaat, Road and Hydraulic Engineering Division, PO-BOX 5044, 2600 GA, Delft, The Netherlands

${ }^{3}$ Rijkswaterstaat, Road and Hydraulic Engineering Division (retired), PO-BOX 5044, 2600 GA, Delft, The Netherlands

${ }^{4}$ Delft University of Technology, Faculty of Civil Engineering and Geosciences, PO-BOX 5048, 2600 GA, Delft, The Netherlands 
Wave impacts on a plate on sand, such as an asphalt dike revetment, cause bending stresses in the material. This can cause yielding of the revetment. For the design of closed dike revetments information is required about the location of the impact point, the highest pressure, the shape of the load, its duration and the distribution of impact pressures in time and space. In 1984 a design method has been presented to determine the layer thickness of an asphalt dike revetment under wave attack. Since that time several investigations in mainly The Netherlands and Germany have provided additional information about both the impact forces and the behavior of an asphalt revetment under wave attack. Therefore it was decided that a new design method had to be developed. As a base for this design method the present knowledge about wave impacts on dike slopes was summarized in a literature survey (Van Vledder 1990) and a first computer program has been established (Meijers, 1993).

In the same period testing of asphalt in the laboratory was started and understanding of the behavior of aged asphalt was obtained. For determining the strength of asphaltic concrete the three-point bending test has been developed.

\section{SCHEMATIZATION OF THE REVETMENT}

In GOLFKLAP, the bending stress in the construction due to wave loads is determined and compared with the failure stress. The construction is schematized as an elastic beam supported by small springs (Winkler foundation). So the construction can be characterized by the layer thickness, the stiffness modulus and the fatigue strength of the asphalt concrete and the modulus of subgrade reaction. The wave impacts are schematized as a serie of triangular loads on the asphaltic concrete layer (see figure 1).

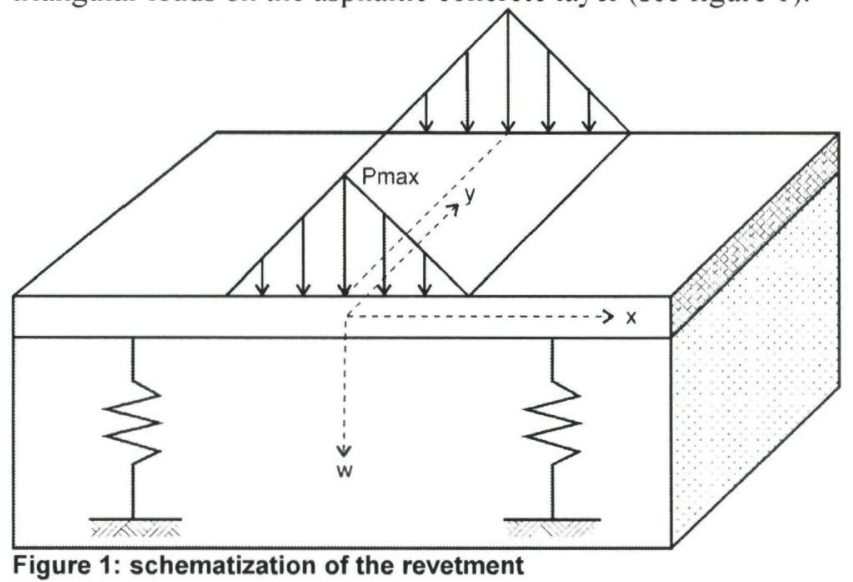

For every wave load the bending stress in the construction is calculated:

For $x=0$ :

$$
\sigma=\frac{p_{\max }}{4 \beta^{2} \beta z}\left[1-e^{(-\beta z)}(\cos (\beta z)+\sin (\beta z))\right] \frac{6}{h^{2}}
$$


With: $\quad \beta=\sqrt[4]{\frac{3 c\left(1-v^{2}\right)}{S h^{3}}}$

In which: $\sigma=$ bending stress at the base of the construction $\left(\mathrm{N} / \mathrm{m}^{2}\right), p_{\max }=$ maximum pressure $\left(\mathrm{N} / \mathrm{m}^{2}\right), z=0,5$ width of the load $(\mathrm{m}), h=$ layer thickness $(\mathrm{m}), c=$ modulus of subgrade reaction $\left(\mathrm{N} / \mathrm{m}^{3}\right), S=$ stiffness modulus of asphalt $\left(\mathrm{N} / \mathrm{m}^{2}\right), v=$ Poissons' ratio of asphalt $(-)$.

The stress distribution along the $\mathrm{x}$-axis can be determined by:

For $x<z$ :

$$
\sigma=-\frac{p_{\max }}{8 \beta^{2} \beta z}\left[\begin{array}{l}
-\sin (\beta x)^{*}\left\{e^{\beta x}-e^{-\beta x}\right\} e^{-\beta z}\{\cos (\beta z)-\sin (\beta z)\}+ \\
\cos (\beta x)^{*}\left\{e^{\beta x}+e^{-\beta x}\right\} e^{-\beta z}\{\cos (\beta z)+\sin (\beta z)\} \\
-2 e^{-\beta x} *\{\sin (\beta x)+\cos (\beta x)\}
\end{array}\right] \cdot \frac{6}{h^{2}}
$$

For $x>z$ :

$$
\sigma=-\frac{p_{\max }}{8 \beta^{2} \beta z} \cdot e^{-\beta x}\left[\begin{array}{l}
\cos (\beta x)^{*}\left\{\begin{array}{l}
e^{\beta z}\{\cos (\beta z)-\sin (\beta z)\}+ \\
e^{-\beta z}\{\cos (\beta z)+\sin (\beta z)\}
\end{array}\right\}+\sin (\beta x)^{*} \\
\left\{\begin{array}{l}
e^{\beta z}\{\cos (\beta z)+\sin (\beta z)\}+ \\
e^{-\beta z}\{\cos (\beta z)-\sin (\beta z)\}
\end{array}\right\}-2\{\cos (\beta x)+\sin (\beta x)\}
\end{array}\right] \cdot \frac{6}{h^{2}}
$$

For every chosen point on the dike slope the program calculates the bending stress at the base of the layer due to every occurring wave load during a storm.

\section{HYDRAULIC LOADS}

\section{Design conditions}

An asphaltic concrete dike revetment is normally only applied above the tidal zone. As the impact point of most waves lie below the still water level, these revetments are hardly loaded by waves during their lifetime. Dikes in The Netherlands are designed to withstand a storm with a probability of occurrence of e.g. 1/4.000 a year. During a storm with these conditions a revetment above the tidal zone will be severely loaded. Therefore only the wave impacts during a design storm are taken into account and other loads are disregarded. The duration of a design storm for Dutch circumstances is 35 to 45 hours.

\section{Still water level}

The change of the still water line during a storm is caused by both the astronomical tide and wind setup. This causes a distribution of the wave loads 
over the revetment. The Dutch directives for safety assessments on dikes (Anonymous, 2002) prescribe to compose the still water line during a storm by superposition of wind setup upon the tidal curve as shown in a typical example in figure 2.

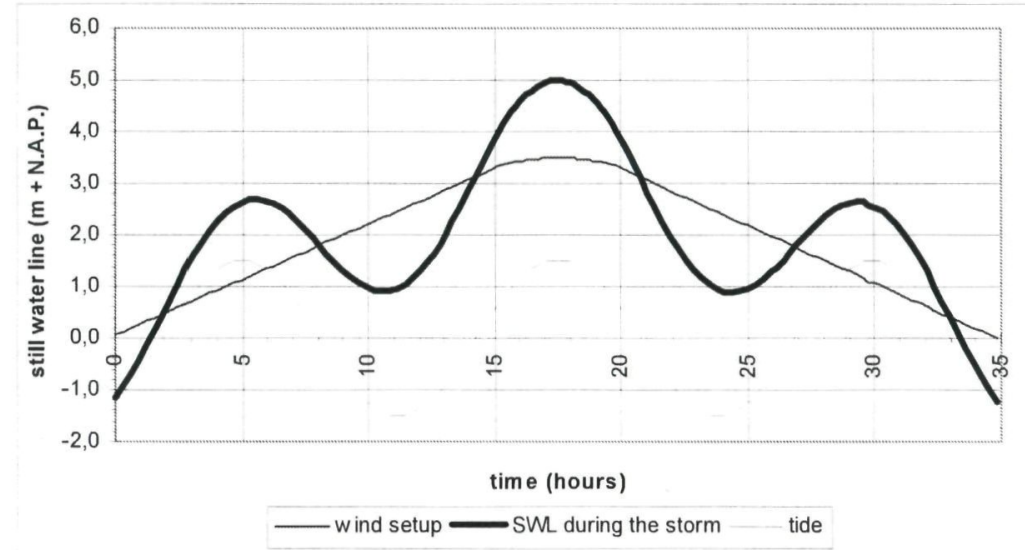

Figure 2 Example of the change of a still water line during a design storm

To take these changes in the water level into account the revetment is divided into small vertical strips. For every strip the time is calculated that the water level stays in each strip. With the average wave period the number of load cycles per strip is determined.

\section{Spatial distribution of the wave loads}

Observations of braking waves on dike slopes indicate that the impact point varies per event. The position of the impact point is defined as the location where the highest impact pressure occurs per braking wave event. Several studies carried out in the period 1970-1990 provide information about the spatial characteristics of braking waves. In GOLFKLAP the spatial distribution of the impact point is based upon field experiments at the Eiderdamm by Grüne (Grüne, 1988). The applied probability density is shown in figure 3. In this figure $\Delta \mathrm{D}=$ vertical measured distance from impact point to still water line. 


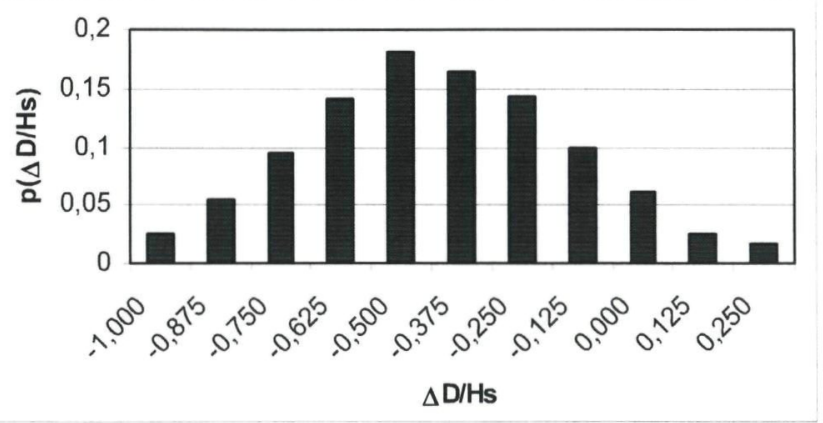

Figure 3 Probability density of the spatial distribution of the impact point

\section{Size of the impact forces}

For practical design methods the maximum impact pressure $\left(p_{\max }\right)$ can be calculated with (Führböter 1986):

$p_{\max }=\rho_{w} g q H_{s}$

In which: $\rho_{w}=$ density of water $\left(\mathrm{kg} / \mathrm{m}^{3}\right), g=$ gravitational acceleration $\left(\mathrm{m} / \mathrm{s}^{2}\right) q=$ factor of impact $(-), H_{s}=$ significant wave height $(\mathrm{m})$. Impact pressures should be considered as a stochastic process. Therefore statistical techniques should be used to describe them. A theoretical distribution for maximum impact pressures was proposed by (Führböter 1966). Based on theoretical considerations a log-normal distribution of the maximum impact pressures was proposed. More recent studies, for example (Führböter 1986) and (Witte, 1988) verified this proposal. In GOLFKLAP the following probability density of the factor of impact is used.

$p(q)=\frac{1}{\sigma_{q} \sqrt{2 \pi}} e^{-\left[\frac{\left(q-q_{m}\right)^{2}}{2 \sigma_{q}^{2}}\right]}$ impact.

In which: $\sigma_{q}=$ standard deviation, $q=$ factor of impact, $q_{m}=$ mean factor of

As a practical approach based on formulae 6 the following probability density for the factor of impact is used in GOLFKLAP (figure 4). The values in the figure are valid for a slope angle of 1:4. 


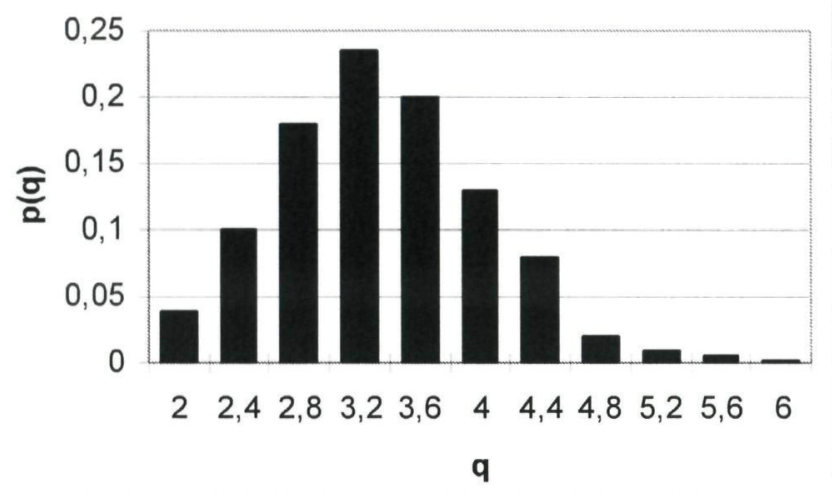

Figure 4 probability density of the factor of impact $q$ for a dike with a slope angle of $1: 4$

Führböter and Sparboom have empirically investigated the relation between the dike slope and the maximum impact pressure (Führböter and Sparboom, 1988). They found that the maximum impact pressure is inversely proportional with the slope $n$. In GOLFKLAP the maximum impact pressure regarding the dike slope is determined with:

$$
p_{\max }=\frac{0,25}{\tan (\alpha)} \rho_{W} \quad g q H_{s}
$$

In which is $\alpha=$ slope angle. The values for the factor of impact $(q)$ are given in figure 4 . The relation is based on experiments with dike slopes of 1:4 and 1:6 and is considered to have a high reliability for slopes with a range of 1:3 to $1: 8$. This means that this approach is applicable for almost every sea dike.

\section{Width of the wave load}

As mentioned earlier in GOLFKLAP the wave load is schematized as a triangular load. In an analysis of the results of large scale tests in the Dutch Delta flume (Ruygrok 1994) it appeared that the width of the wave load varies enormous. No specific quantitative information about the distribution of the width of the load was generated. But having observed hundreds of wave registrations it was assumed the significant load width is equal to the significant wave height. So in GOLFKLAP a Raleigh distribution is chosen as shown in figure 5 , in which: $z=0,5$ of the load width, $H=$ wave height. 


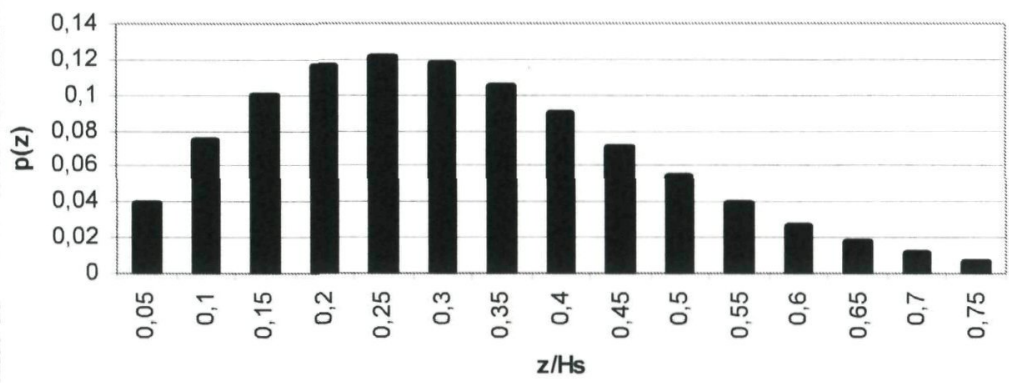

Figure 5 Probability density of the width of the wave load

Further investigation to provide scientific based information about the width of the wave load and the distribution of it is advised.

\section{MECHANICAL PROPERTIES OF ASPHALT MIXES}

\section{Stiffness modulus}

The mechanical properties of asphalt mixes are particularly influenced by the behavior of the bitumen. An asphalt mix is a visco-elastic material which appears to be elastic under short loadings and at low temperatures and more viscous under long duration loadings and at high temperatures. Under wave attack asphalt mixes are assumed to behave elastic. The stiffness modulus $S$ of bitumen and asphalt mixes is dependent on the frequency (or loading duration) and the temperature at loading. The stiffness modulus is used to characterize the material:

$$
S(f, T)=\frac{\sigma}{\varepsilon}
$$

The stiffness modulus can be derived with the use of a falling weight deflectometer on the revetment or with for example three point bending tests on specimen taken from the revetment.

\section{Fatigue}

Asphalt is sensitive to fatigue, i.e. the failure stress (or fatigue strength) of asphalt depends on the number of load cycles. The value of the failure stress reduces with the increase of the number of loads. The fatigue properties can be expressed with:

$$
N_{f}=k \cdot \sigma^{-a}
$$

Or: 
$\log \left(N_{f}\right)=\log (k)-a \cdot \log (\sigma)$

In which: $N_{f}=$ number of loads to failure at a size $\sigma, \sigma=$ applied bending stress $\left(\mathrm{N} / \mathrm{m}^{2}\right), a$ and $k=$ coefficient and intercept of the fatigue curve. The fatigue strength of an asphalt revetment is normally derived with three point bending tests on specimens from the revetment.

\section{MINERS RULE}

Every load adds damage to the construction. To determine whether the revetment is capable of resisting the occurring sum of wave loads, Miners rule is used. For each applied $n$ load cycles of a certain stress level on the material, which has a loading cycle number at failure of $N$, the amount of damage to the construction will be proportional to $n / N$ :

$$
\sum \frac{n_{i}}{N_{f, i}} \leq 1
$$

In which: $n_{i}=$ number of loads at stress level $\mathrm{i}, N_{f, i}=$ number of loads to failure at stress level $i$. The revetment will yield if the Miner sum exceeds 1 .

With the described statistical distribution of the place, magnitude and width of the impact pressures the loading due to wave impacts during a storm can be determined. GOLFKLAP calculates the Miners sum for chosen points on a cross section. An example of a result of a calculation with GOLFKLAP is shown in figure 6 .

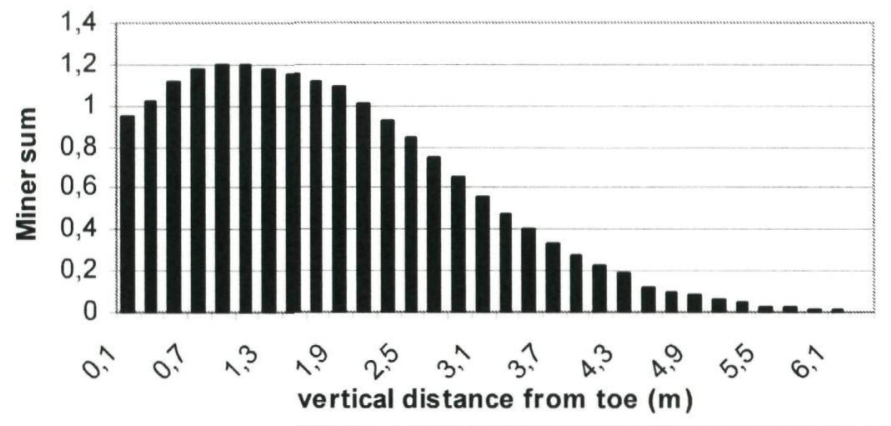

Figure 6 Result of a calculation with GOLFKLAP

\section{DATA COLLECTION}

\section{Field surveying}

To execute a safety assessment of an asphalt dike revetment, a good insight into the most important parameters of the construction is necessary. Most of the 
asphalt revetments are older than 20 years. The strength and the stiffness of an asphalt revetment can change in time and the variation of these properties increase. Changes in the strength are assumed to be related to the changes in the stiffness modulus. The stiffness modulus is determined to be able to calculate the stresses in GOLFKLAP, but can also be related to the fatigue behavior of the mix. Therefore the stiffness modulus is determined with a falling weight deflectometer (FWD). The layer thickness is determined with ground penetrating radar (GPR). An advantage of these techniques is that they are nondestructive. Both methods combined give a good insight in the quality of the revetment and are frequently used in Dutch practice. With the results weak spots in the revetment can be allocated. From these weak spots cores are taken for laboratory tests to determine the relation between failure stress and number of load cycles.

\section{Laboratory tests}

The survey with a falling weight deflectometer is carried out under natural conditions in which the asphalt temperature might vary. Because the stiffness modulus of asphalt mixes is depended on the temperature the results have to be normalized to one temperature. For Dutch circumstances this temperature is chosen to be $5^{\circ}$ Celsius as a representative value for severe storms occur during the winter season. A correction for the frequency of loading is performed as well. The frequency of loading of a falling weight deflectometer is $15-20 \mathrm{~Hz}$. The stiffness moduli are normalized to a frequency of $10 \mathrm{~Hz}$. because the loading time of a wave impact pressure is approximately $0,1 \mathrm{~s}$. Normalizing the stiffness moduli is done with master curves (which records the relation between the stiffness modulus and the temperature/frequency of loading) based on frequency sweeps. Frequency sweeps are performed by several temperatures on specimen taken from the revetment, for example in a three point bending test.

The fatigue properties of the revetment are derived with the three point bending test as well. A representative number of specimens from the revetment are tested to failure by various stress levels. Fatigue tests are carried out at $5^{\circ}$ Celsius and $1 \mathrm{~Hz}$. This is assumed to be an representative frequency for a loading time with a short duration (approximately $0,1 \mathrm{~s}$.) and a relaxation time of several seconds which are the circumstances during a storm. More information about the three point bending test can be found in (Montauban and Van de Ven, 1993).

\section{CONCLUSION AND FUTURE DEVELOPMENTS}

In combination with non-destructive measurements like radar and falling weight deflection GOLFKLAP is a powerful tool for both designing and performing safety assessments on asphalt dike revetments. In the last years several safety assessments have been carried out with GOLFKLAP and the described non-destructive measurements. In these assessments the fatigue properties were derived with three point bending tests. 
In the future further improvements will be implemented in the program. Based on the results of more recent tests in the Delta flume a study will be performed to improve the description of the wave loadings on the revetment. In addition to this a method will be developed to evaluate an asphalt revetment on one extreme wave impact with a small probability of occurrence. For this purpose a new material test has to be developed and adjustments to the program have to be made.

\section{REFERENCES}

Anonymous, 2002. De veiligheid van de primaire waterkeringen in Nederland, Voorschrift toetsen op veiligheid voor de tweede toetsronde 20012006 (VTV), (in Dutch) Rijkswaterstaat.

De Looff, A.K., Van Vilsteren, I.H.B., Eigeman, P.M. 2004. Gebruikershandleiding GOLFKLAP 1.2 (in Dutch). KOAC-NPC report e038390, Utrecht.

Führböter, A. 1966, Der Druckslag durch Brecher auf Deichböschungen. Mitt. Franzius-Institut, Technische Universität Hanover, Heft 28 (in German).

Führböter, A. 1986. Model and prototype tests for wave impact and run-up on an uniform 1:4 slope. Coastal engineering, vol. 10, 49-84. Elsevier Science Publishers, Amsterdam.

Führböter, A., Sparboom U. 1988. Shock pressure interactions on prototype sea dikes caused by breaking waves, Proceedings International Symposium on modeling soil-water-structure interactions, SOWAS 1988, Delft.

Grüne, J. 1988. Wave-induced shock pressures under real sea state conditions. Proceedings $21^{\text {st }}$ International Conference on Coastal Engineering, 2340-2354.

Meijers, P. 1993. Ontwerpmethodiek bepaling asfaltdikte taluds onder golfbelasting - fase 2 (in Dutch). GeoDelft report CO-337630/9, Delft.

Ruygrok, P. 1994. Dimensioneren van asfaltbekledingen op golfklappen, analyse van de relatie tussen golfbelasting en rekken (in Dutch), CO-347160/17 Grondmechanica Delft.

Montauban, C.C. and Van de Ven, M.F.C. 1993. Determination of mechanical properties of hydraulic asphaltic concrete by means of a three-point bending test, Eurobitume conference 1993.

Van Vledder, G. Ph. 1990. Literature survey to wave impacts on dike slopes. Delft Hydraulics report H976, Delft.

Witte, H.-R.R, 1988. Theoretische und expirimentelle Untersuchungen ober den Druckslag bei Wellenangriff auf einen 1:4 geneigten Seedeich (in German). Mitteilungen Leichtweiss-Institut für Wasserbau, Technische Universität Braunschweig, 401-453. 